\title{
Supporting Lecturers in the Disciplines in the Affective Academic Writing Process
}

Roisin Donnelly

Technological University Dublin, roisin.donnelly@tudublin.ie

Follow this and additional works at: https://arrow.tudublin.ie/ltcart

Part of the Education Commons

\section{Recommended Citation}

Donnelly, R. (2014) Supporting Lecturers in the Disciplines in the Affective Academic Writing Process, Journal of Academic Writing Vol. 3 No. 2, 2014, pages 61-69.

This Article is brought to you for free and open access by the Learning Teaching \& Assessment at ARROW@TU Dublin. It has been accepted for inclusion in Articles by an authorized administrator of ARROW@TU Dublin. For more information, please contact arrow.admin@tudublin.ie, aisling.coyne@tudublin.ie, gerard.connolly@tudublin.ie. 


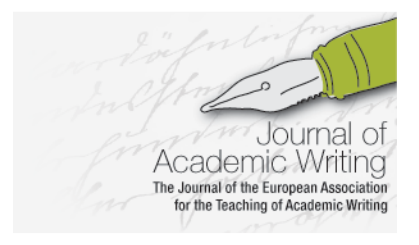

Journal of Academic Writing Vol. 3 No. 2, pages 61-69

\title{
Supporting Lecturers in the Disciplines in the Affective Academic Writing Process
}

\author{
Roisin Donnelly \\ Dublin Institute of Technology, Ireland
}

\begin{abstract}
This article reports on a case study evaluating lecturers' experiences of their own affective writing process using a reflective critical incident analysis. While the cognitive-affective focus of academic writing has been explored previously from a collaborative perspective (Benton et al. 1984), this current study takes the individual writer as the unit of analysis. There are several reasons why lecturers need to write. Foremost among these should be when they write, they are providing a positive model for students, and are helping demystify the act of writing. Scholarly writing can be a struggle, and by doing so ourselves, we learn empathy for our students. In reality, many lecturers are facing the need for increasing their publications output. In terms of writing for publication, Murray (2013) has advised that busy academics must develop productive writing practices, and this may mean changing writing behaviours.
\end{abstract}

Affective conditions such as a sense of class community, self-efficacy and writing apprehension are known factors affecting writing behaviour and performance. A blended accredited professional development module entitled 'Writing and Disseminating Research' is discussed as a way to afford lecturers opportunities to develop writing skills that may also promote positive affective conditions. Data suggests that this pedagogic intervention resulted in greater confidence in terms of participants' critical writing skills and provided a suitable environment for affective conditions to flourish. Four themes emerged from the analysis of the critical incidents on writing apprehension: self-efficacy, the role of external sources on affective writing, peer feedback and class community. Future research would explore the sustainability of the process extending into lecturers' own practice with their students.

\section{Introduction}

Academic writing has long been acknowledged as a complex process both to undertake and to teach. While many studies have explored various aspects of lecturers' perceptions about teaching writing across different contexts (Moore 2000; Björk et al. 2003; Murray 2006), there is a lack of evidence from the higher education professional development context and perspective. Student academic writing continues to be at the centre of teaching and learning in higher education, but is often an invisible dimension of the curriculum. Historically the conventions of academic writing have not been explicitly taught within disciplinary courses.

There have been studies to address particular facets of the writing support role, but what has been largely missing from the discussion are the views of lecturers regarding the strategies they use to develop academic writing in the discipline. A study by Arkoudis and Tran (2010) reveals that academic writing within the disciplines is largely an individual endeavour for both lecturers and their students. Lecturers focus on explaining what skills students are required to demonstrate in their assignments, but students are more concerned with understanding how they can develop these skills. 
This current study proposes that it is important to be explicit about the connection between teaching lecturers to write and raising their capacity to teach their students to write. The challenges facing lecturers in supporting their students in the writing process centre around the key areas of assessment and learning. Students across the disciplines may be required to produce essays, written examinations, or laboratory reports whose main purpose is to demonstrate their mastery of disciplinary course content. In assessing such writing, lecturers focus on both the content and the form of the writing, which is the language used, the text structure, the construction of argument, grammar and punctuation (Coffin et al. 2003). Students also need support which can help them engage with disciplinary knowledge as well as develop more general abilities to reason and critique (Hilgers et al. 1999). Specifically they may be required to write texts that trace their reflections on the learning process itself, as with journals where they record thoughts, questions, problems, and ideas about readings, lectures, and applied practice. So where does the role of writing confidence fit in?

The affective conditions of academic writing issues have tremendous impact upon both process and product (Bruning and Horn 2000). It can be useful to offer a definition of affective in the context of this study. McLeod (1991) explored a number of useful working definitions of the affective domain and the writing process; many considered the role of emotions in relation to writing and all centred on building learners' confidence in their writing ability. A recent book edited by Clughen and Hardy (2012) focuses on students as writers and the affective domain. It includes a range of teaching practices that have been successful in increasing students' confidence and ability in writing. Students need to be dedicated and engaged in order to devote the time, effort, and emotion necessary for successful academic writing.

Previous research studies have tended to concentrate on motivation and deal primarily with primary, secondary, or collegiate populations (Pajares 2003). Investigations of writing and motivation have focused largely upon self-efficacy. Past inquiries involving student selfreporting have used instruments such as multiple-choice surveys and rating scales almost exclusively, thus restricting the extent to which writers' voices have been heard. This study sought to begin to redress these gaps by using critical incident analysis. This critical incident approach, which has its origins in Psychology (Flanagan 1954), is used widely in Health Science education (Mahajan 2010) and increasingly in teacher education contexts and was chosen for this study because of its value in encouraging one to question an aspect of beliefs, values, attitude or behaviour. In the module on 'Writing and Disseminating Research' on which the current study focused, it was an incident which in some way had a significant impact on the participants' personal and professional approach to their writing. How it differs from previous instruments used to explore the affective domain is that it provides an approach to structuring the process of reflexivity within this practice learning context, and is useful for developing reflexive writing (Green Lister and Crisp 2007).

Undoubtedly there are challenges for academic developers in their role in instructing lecturers to support their own students in writing. In the context of this study, the term 'academic developer' can be defined as '....any person who has a role in which they are explicitly expected to work with academics to assist them to reflect upon their academic role in relation to teaching, research, scholarship, leadership, and supervision of students' (Fraser 1999: 90). The academic developer in this study was the module lecturer who taught on the 'Writing and Disseminating Research' Module.

\section{Context}

A core module for an MA programme in Higher Education in an Irish higher education institution entitled 'Writing and Disseminating Research' was the focus of this study. The module, which was first taught in 2009, was developed in acknowledgement that there are ever-increasing pressures on academics to undertake research and to publish both in their own disciplines and in higher education pedagogy, practice and policy. The module is aimed at higher education lecturers who wish to help their own students improve their academic writing in discipline-specific contexts. It was anticipated that the module would combine a 
practical orientation to teaching writing with a grounding in current theories of writing instruction. The specific purpose of the module was to teach academics more about their own writing processes so that they, in turn, will have the understanding and the tools to become better-equipped teachers of writing to the students they themselves teach in their instructional role. Although the 16 participants on the module were all academics, they were engaging as postgraduates on the MA programme.

By providing key knowledge and support to those academic staff interested in publishing in teaching, learning or eLearning professional practice, the module is an attempt to help participants' work to become the focus of a form of sustained inquiry, leading towards publication. Through exploration of a wide variety of practical academic writing tools, the intention is to progress well-planned research work along the road to publication. Key to participant success is the honing of both written and oral communications skills through extensive writing practice and presentation in a selected area of their choice. Principles of academic writing are investigated along with the necessary skills of advanced information literacy.

An exploratory model is proposed for critical academic writing encompassing a series of scaffolded in-class activities, virtual peer learning, and blended feedback from the module lecturer - culminating in the publication and dissemination of individual practice-based educational research. These two practical outputs from the module, as each participant writes a paper for publication in a peer reviewed journal and makes a conference presentation on their practice-based research, have been designed to support lecturers with academic writing in their discipline. A diverse and contemporary range of topics from practice have been published to date including: research on the use of wikis to support collaborative learning in Marketing; stories from higher education technology-enhanced learning; a practical approach to teaching students with dyslexia; active learning techniques in legal professional education; project management skills for apprentices in construction; problem-based multimedia learning; cognitive research in first year chemistry; and effective tutorials in professional education.

Figure 1 shows the different components of the blended module. Integration of online and face-to-face class (f2f) activities for writing development saw an online journal club being introduced as well as virtual peer learning sets. The journal club took place in the Institution's virtual learning environment, Blackboard, and was aimed at helping participants learn how to read articles critically. Provocative articles on the role of academic writing were chosen for review, and participants worked in small groups to appraise a recently published research paper, and present their findings to their peers in the online journal club. Initially, participants expressed that they did not feel confident in their critical appraisal skills, so checklists for critical review were made available online. While they were confident as lecturers in their own subject areas, many felt unsure about their critical appraisal skills when asked to conduct peer review of a colleague's written draft. The advantage of the online club approach is that reviews are more consistent and they alert the readers to any methodological flaws. Incorporating learning principles such as agreeing goals relevant to participants was used to enhance the learning experience. Group theory (Johnson and Johnson 2003) suggests that clear boundaries contribute to a sense of security, making creative thinking possible.

The peer learning sets were virtual to allow the participants to maintain the dynamic and pace of their learning between f2f classes. It was integral to the impact of these sets that investment was made in establishing mutual trust amongst the participants as part of the f2f module induction, as such peer exchange is rooted in existing relationships and a certain degree of reciprocated faith. Boulton and Hramiak (2012) have researched writing in the virtual environment, including the development of reflective communities of learning through the use of shared online web logs. It was established early on in the module that peer exchange necessitates a minimum shared knowledge of the context so as to make sense of what peers have to say about their work; key to success is a will to learn on the part of all the participants. That will to learn implies that participants need to be able to admit that they do not know all the answers, which in turn requires there to be mutual confidence and a relatively 
non-threatening atmosphere within the virtual peer set. Arguably writers require both social and academic integration in order to successfully complete their work in a timely fashion. Creating opportunities for social and academic interaction with other participants was of vital importance for setting a positive affective climate for writing. By providing personal support, the virtual peer sets were based on openness and individual commitment to one another, which helped participants develop the ability to combine criticism with support and also serve as a first filter for ideas and shared resources. The emotional side of writing is usually privatized and often under-communicated (Baikie and Wilheim 2005), so the participants were encouraged to exchange experiences, frustrations and discuss writingrelated issues. Having an open-hearted manner and communicative frame of mind by all involved, which they interpreted as trust, was central to its success. The key to engaging writers in the virtual environment is the creation of a space where they feel comfortable, trusted, and valued.

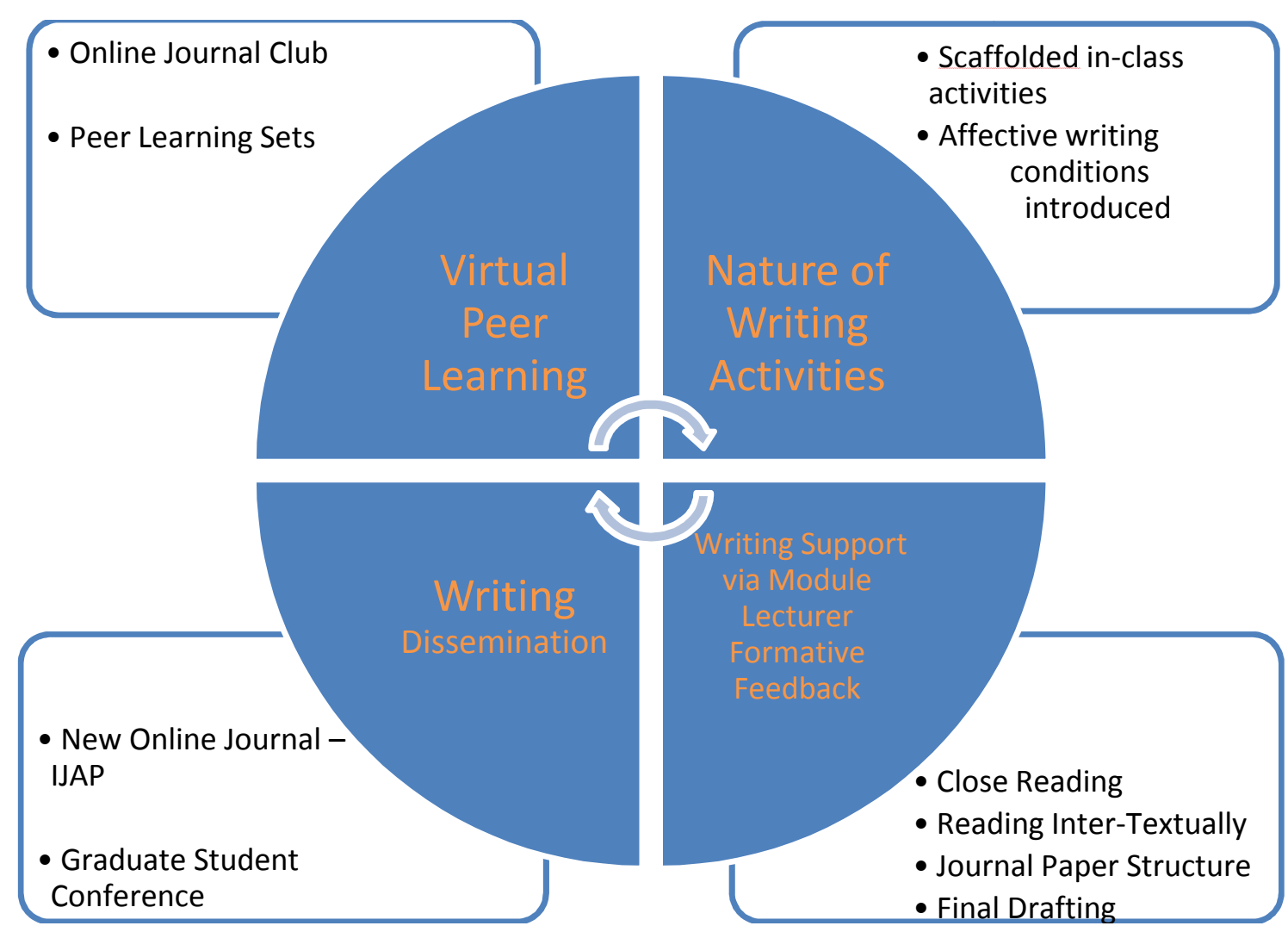

Figure 1. Exploratory Model of Supporting Affective Academic Writing

The scaffolded in-class activities, where the concepts and practices of academic writing were introduced, drew on well-recognised writing exercises (e.g. from Crème and Lea 2003) dealing with criticality. Although teachers are able to articulate the critical thinking skills that they would like their students to exhibit, the cognitive steps between actual student performance and desirable student performance often remain unarticulated and vague. Formative feedback provided by the module lecturer centred on the importance of close reading, reading inter-textually, and on structuring a journal paper. Participants were learning that academic reading is not a passive activity and to become a good academic reader they must approach the text as something that needs a response from them.

In terms of writing dissemination opportunities resulting from this module, two outlets for the participants' work have been introduced - a student conference to celebrate their work and a new journal entitled Irish Journal of Academic Practice (IJAP). Special emphasis in the journal is on innovative practices in teaching and learning. The purpose of the graduate conference is to disseminate educational research from across the programme (involving both present and 
past graduates), which is relevant and interesting to all academics. The conference is a way to build a network of research-informed participants and by encouraging such networking, it is anticipated that the event will also reinforce participants' understanding of the value of involvement in communities of practice associated with academic disciplines and professions. This conference focuses attention on how learning and academic writing happens, as well as how it is experienced in different subject contexts; specifically it encourages participants to critically reflect on their thinking and learning about educational research in which they are currently engaged, and to share these reflections with others.

\section{Supporting the Affective Writing Process}

Contemporary theory and practice in writing pedagogy acknowledges that the nature of the writing process is fundamentally social. Arndt (1992) argues that writing is seen not as a decontextualised solo performance, but as an interactive, social process of construction of meaning between writer and reader. More recently, funded projects on developing collaborative academic writing communities have emerged (Speedy 2010). However, historically cognitive aspects of the academic writing process have received particular attention as practitioners and researchers have attempted to understand the thought processes underlying the compositions of students (Flower and Hayes 1981; Scardamalia, Bereiter and Goelman 1982). Björk and Räisänen (2003), for example, focus on the cognitive processes, and related development supports required in four stages of writing: prewriting activities, drafting, feedback/revision, and evaluation/grading.

As writing is as much an emotional as a cognitive activity, studies have been undertaken to explore the affective factors that influence writing (Beach 1989; Faigley et al. 1985). Some have suggested that students' self-perceptions of their own writing competence offer a particularly promising avenue of research for informing writing instruction (Beach 1989; Pajares 2003; Carter 2008). A study by Pajares (2003) found that students' confidence in their writing capabilities influences their writing motivation as well as various writing outcomes. It has been shown that learners with high self-efficacy see difficult writing tasks as challenging and work attentively to master them, using their cognitive strategies productively (Lavelle 2006). Demirel (2011) explores the effects of using a multiple-draft process approach on reducing students' anxiety levels, as they relate to the academic writing process. O'Connor and Petch (2012: 82) believe that 'writing must [...] be thought of as a form of truth emerging from self-development'.

However, the results of a correlational study by Al-Mekhlafi (2011) on trainee-teachers' perceptions show that there is no significant relationship between the subjects' self-efficacy beliefs about themselves as writers and their performance in a writing course. The study reported on in this article was concerned with teaching lecturers to draw upon their own knowledge and performance as writers to enable them to teach writing more effectively to their own students. As such, an article by French (2011) was influential; it focussed on the different ways the participating lecturers in her study had tried to support students' writing development, as well as the extent to which they felt responsible for developing writing as part of their specific subject teaching.

Therefore, the literature contains a number of research studies that address the perceptions, beliefs and attitudes of students in primary, secondary and higher education, and how these may change over time, but there seems to be a relative lack of studies that examine the relationship between academics-as-students' perceptions of themselves as writers, their affective performance in writing, and how their ability to write translates into skill in terms of teaching writing. 


\section{Methodology and Method}

Critical incident analysis was used to capture participants' experiences of affective writing. Despite a lack of consensus in the literature as to the precise defining characteristics of a critical incident, Tripp's (1993: 24-25) definition works effectively as a contextualising framework. He defines critical incidents as:

straightforward accounts of very commonplace events that occur in routine professional practice which are critical in the rather different sense that they are indicative of underlying trends, motives and structures. These incidents appear to be 'typical' rather than 'critical' at first sight, but are rendered critical through analysis.

Critical incidents have been utilised as a learning tool in many professional disciplines including education (Kuit, Reay and Freeman 2001). The learning in this context centres on the reflective analysis facilitated via selection and consideration of a critical incident. Similarly, in the present study, participants were guided to reflect on key learning points encountered during the academic writing process. The critical incident technique in this context was chosen for its strength in providing 'a systematic means for gathering the significances others attach to events, analysing the emerging patterns, and laying out tentative conclusions' (Kain 2004: 85).

Participants were asked to describe a critical incident or event through producing a written reflection-something significant from their writing experience-from which they could extract in-depth learning. This written reflective critical incident was included as part of a qualitative questionnaire, which had a number of questions present that probed for an explanation and consideration of impact of the critical incident. While a critical incident is generally something which can be interpreted as a problem or a challenge in a particular context, rather than a routine occurrence, in this study it was to be something that stood out for the participant, e.g. a successful or unsuccessful writing or publishing incident, on which they could reflect. Other examples might include conversations with peers in the 'Writing and Disseminating Research' class, a moment when they felt they were beginning to make progress with their writing, or a motivational strategy they found useful for progressing their writing. Critical incident analysis lends itself to research that seeks context-rich, first-hand perspectives on experience. Broader patterns and themes can be discerned, which can in turn illuminate 'shared reality' (Kain 2004: 82).

\section{Findings and Discussion}

As part of the ethical dimension to this study, all participants' permissions were obtained through statements of informed consent. Specific permission was acquired for using any extracts from writing the critical incident. Data collection regarding critical incidents can be undertaken in many ways: through personal interviews, focus group interviews, and direct or participatory observation. As previously stated, for this study, written reflective critical incidents were used along with an open-ended questionnaire, gathering retrospective data. A framework for analysis by Edvardsson and Roos (2001) was considered which focused on the three main areas of cause, course and result of the critical incident. However a decision was taken to use the approach advocated by Angelides (2001) who argued that an analysis of critical incidents can be used by researchers interested in collecting qualitative data quickly as a method for doing a case study. Further, the fact that this approach can be used in a participatory way to contribute to understandings about the affective writing process for the purpose of improvement was why it was chosen.

The critical incident accounts were analysed by the module lecturer. The analysis was carried out by first reading through the written reflections several times, and then identifying the content or themes represented by clusters of incidents and conducting 'retranslation', during which the incidents were sorted into content dimensions or categories. These steps helped to 
identify incidents that were judged to represent dimensions of the affective writing behaviour being considered.

Four themes emerged from the analysis of the critical incidents on writing apprehension: self efficacy, the role of external sources on affective writing, peer feedback and class community. Figure 2 shows these emerging themes as impacts on the affective writing process:

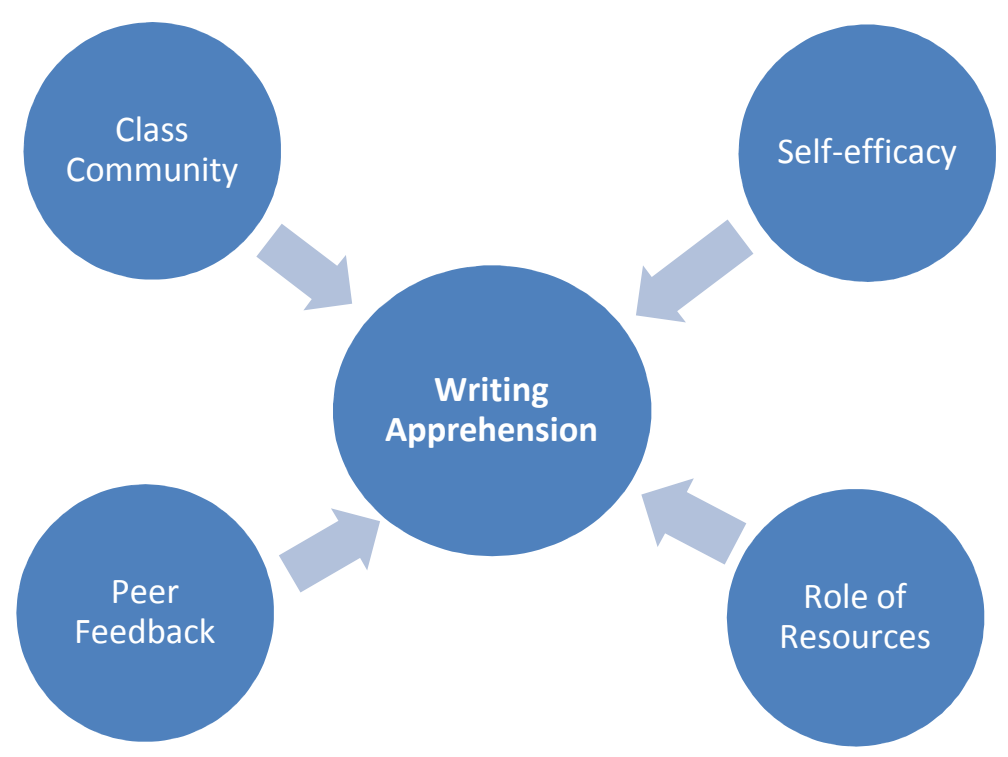

Figure 2. Impacts on the Affective Academic Writing Process 


\title{
Features of the critical incident: writing apprehension
}

A vignette written by one of the participants is included to highlight a specific critical incident relating to the effect of writing apprehension.

\begin{abstract}
When and where it happened: At home in front of my pc, March 2011; I reviewed the work I had written to date, and was very unhappy with it and anxious about the outcome-in my accompanying reflection, I described the piece that I wrote as 'poor quality', and I certainly wouldn't share it with anyone. I felt that I distracted myself enough by reviewing the writing texts assigned (Moore and Murray), and tried some of the writing techniques, such as outlining and freewriting, which added word count, but not much improvement in quality. I suppose I then put that work aside as 'preparatory' and then just decided to write it as a draft, and leave the critical voice in my head for the redrafting stage [Bold added]. At the time I was annoyed with myself for finding this task so difficult. I also realised that by this stage I had done most of the hard work-implementing the wikis-moderating and supervising the projects, and implementing the survey. I signed up for this module (which was optional for me) as I have long wanted to begin publishing but was not sure how to begin. I really felt that this was a long awaited opportunity that I was determined not to waste. Afterwards I felt a great sense of achievement in having completed the task, and having the paper accepted at a conference felt like a validation, and spurred me on to submit (and present) two other papers to conferences, which was a lot of work, but a very good experience. [Business Lecturer]
\end{abstract}

\section{Figure 3. Example of a Critical Incident}

In a follow-up question on the critical incident, this participant was asked to explain why this incident stood out so clearly in her mind, and why she appeared to have lost confidence in her ability to function as a writer in an academic environment:

I suppose because it [writing] was a skill I really wanted to acquire for some time and as I lacked confidence in my ability, I found it really difficult when I sat down at it - I thought that there was a magic 'writing gene' that only some people have! In reality writing takes practice, but it's difficult to continue sitting, when no writing is happening. [Business Lecturer]

The reflections that participants made through writing the critical incidents allowed them as writers to express their uncertainty about their ability. Gazin (2003: 32) reports that critical incidents may offer a 'mechanism for self-reflection'. Certainly on the module, the critical incidents triggered the expression of thoughts and emotions for many of the participants. As such, it was important for the module lecturer to take into account the lack of confidence many of the participants had developed in their scholarly writing as a result of previous experiences or of present academic difficulties. Other participants also experienced similar challenges in their writing, and began attributing them to a lack of confidence:

\section{Maybe I was battling with my demons, and trying to encourage myself! [Biochemistry Lecturer]}

I was not sure why I found the actual writing so difficult, I have had some fiction published, and my English essays in school were always good. Writing this response has forced me to think about it more deeply, and I believe this particular task exposed my lack of confidence as an academic, through not having a postgraduate qualification, or any publications and this module has been instrumental in helping me to overcome this. [Hospitality Catering Lecturer]

\section{I feel it [academic writing] was a big obstacle to overcome. [Computing Lecturer]}

This was my first experience of academic writing; I think I may well have avoided it up to now. [Electronics Apprenticeship Lecturer] 
In order to make best use of the critical incidents strategy, as Gonzalez et al. (2003) advocate, when referring to the type of incidents, it is important to consider the overall context, time, place, participants, actions taken and resolution of the event. After that, reflection and evaluation of the incident helped with both the reviewing of the teaching and learning experience and exploring any changes in participant writing behavior.

'Looking for Clues' was the name given by one of the participants to the critical incident for the stage of initial preparation for the article he was writing, when he could not come up with an idea as to what he wanted to write about or how to write it:

I felt hopelessly inept, and that I had taken the wrong MA module choice. In addition I felt like the only person in the class who felt like this. I later found out that half the class also felt like this which was something of a comfort. I suppose this was the point at which I was going to 'fight or flight'. I would have quit if the feelings had persisted. [Marketing Lecturer]

Other participants had similar initial feelings of anxiety about writing; it was useful to be upfront about this issue with the participants and time at the end of each class was devoted for discussion of feelings and attitudes to the academic writing process and how they were evolving as time went on:

[I had a] sometime feeling that I had not a clue what I was doing there. Also that I did not have the skills to write/ produce or research the article. [Construction Apprenticeship Lecturer]

I had this thought several times early on - 'Thank God I'm not the only one in this boat!' [Law Lecturer]

The support provided to these anxious academic writers was paramount in the early stages of the module to ensure that any crises of confidence were short-lived; especially important was to ensure that it would not have a lasting negative impact on their own writing practice into the future, and indeed have a detrimental effect on how they supported their own students in writing:

What helped most was the module's lecturers and recognising that some of the other students were also finding it difficult, and that perfect writing doesn't come with the first draft. [Economics Lecturer]

I got most help from the module's lecturers who seemed to understand my writing dilemmas. Also recognising that the work I engage [sic] in had a personal element to it made it easier to engage in critical self-reflection and to subsequently write about. And of course time. The more time I spent in [the module], the more work I did; and the more feedback received; this helped me move nearer my goal of completing the article AND the module. [Law Lecturer]

The module's lecturers allowed me to feel like I can 'trust the process' a bit more. Their feedback also gave me the confidence to write and trust that what I wrote wasn't a load of rubbish. I also learned much from researching and reading. In addition it gave me a good insight into how to treat students in my role as a teacher; and to be aware of how personal and/or other issues can 'block' learning. It made me a better teacher. [Biochemistry Lecturer]

Some of the other students write beautifully; I found the support of others very helpful, both in terms of competitive 'spurring on' and offering a good sense of community. [Marketing Lecturer]

[This module] was my first ever piece of scholarly writing, Since then l've written two other conference papers, and a research methods paper, all with positive 
feedback. I hope now to continue to develop this skill and go back to the literature on writing again. [Accountancy Lecturer]

Participants were asked if there was a particular mindset that contributes to the event. Graham and Harris (2000) proposed that the development of writing competence depends on high levels of self-regulation. This was mirrored in the responses:

Definitely. I can be prone to the poor-me's!! [sic] I also did not know anybody in the class and did not feel able to ask for help. [Computing Lecturer]

Without a doubt. I initially chose this module because I felt writing an article would be easy considering the track record of writing publications during my PhD. I immediately realised this was not the case once the module had started and I felt I would struggle. The support given to me by this peer group was immense and combined with the strong guidance of [the module lecturers] I found my mindset going into this event was completely reversed. [Management Lecturer]

What was I going to do? Was I going to work harder and get into it or quit? In addition how can my future students be helped when in a similar situation? There was a sense of community in the class. Although a core group within the class did know each other from working in [the institution], there was good enough support particularly in the areas of self-efficacy and writing apprehension. [Economics Lecturer]

Murray and Moore (2006: 145) have pointed out that not all academics have practised writing behaviours that are likely to lead to publication, and that 'discovering and maintaining productive writing habits is not a straightforward process for all'. However, there are mechanisms such as peer review and emphasising being part of a writing community which can help the formation of improved writing habits.

\section{Self Efficacy: role of peer review and class community}

A major finding was that teaching lecturers how to practice peer review of their writing and the writing of others was a turning point in the module's goal of teaching lecturers about how to teach writing to their own students. Creating opportunities for students to read and respond to one another's writing is a well recognised strategy in writing groups and classes around the world. As the participants in this module were all academics who were familiar with using peer review techniques with their students in their own practices (this was a question on the qualitative questionnaire), it was important to build upon this knowledge and ensure that clear guidance on the process was given so that they would know how to comment on one another's writing in a specific and constructive way. As Nilson (2003) advocates, part of the process involved emphasizing to the participants that peer review is an essential part of the writing process that all successful writers engage in at some point. Participants responded positively to their engagement in the peer review process, which took place at several points in the module, and was often most helpful to the writers when it was utilized between the drafting and revision stages of their journal papers:

It gave me more confidence I suppose, therefore allowed me to be more open to take risks in my writing. We were split into writing support groups, consisting of 3 or 4 of our peers and met as a group and told each other what we had planned to write our article on. We then each submitted a draft to the group and the group then gave feedback to one another on the content and direction of the articles. [Computing Lecturer]

The group gave feedback to one another on the respective articles but also gave an insight into our own experiences of the module to date and the journal paper each person was writing. It was reassuring to hear from my colleagues that they also found the module challenging. As well as feeling relieved by the sharing of our experience, the constructive criticism given by the group made me feel like I 
could actually produce a really good article in the end-reassurance that I could reach the light at the end of the tunnel. [Economics Lecturer]

It was the turning point in this module. The positive element of the feedback from the group also made me feel like my article was of interest to lecturers so it made me feel like the 'struggle' to write the article was very worthwhile. [Construction Apprenticeship Lecturer]

I felt like this module was the transition stage for me-l am a scientist by trade and through the course of my PhD have published eight scientific papers before starting this module. Writing an education based article was a whole new ball game for me and [the] learning curve was very steep. [Biochemistry Lecturer]

Peer evaluation is a very useful teaching tool. The first question I now have is how do I bring something like this into my own teaching? [Economics Lecturer]

Where I am now in terms of my appreciation and understanding of academic writing is miles ahead of where I was several months ago - practically worlds apart. [Business Lecturer]

Bransford, Brown and Cocking (2000: 59) emphasize that 'students need feedback about the degree to which they know when, where, and how to use the knowledge they are learning'. The peer review process is certainly an integral component of this module in deconstructing the writing dilemmas of the participants and opening up for them a mutual way forward for building their confidence as writers. Cooper and Mueck (1990: 71) note: 'The most consistent positive findings for co-operative learning [...] have centred on affective or attitudinal change'. This was also found to be the case on this module and slowly building up a sense of class community helped the majority of the participants.

\section{Role of external sources on affective academic writing}

The external sources used in the module were a combination of relevant literature, research, theory, video reflections and digital scholarship on the academic writing process. Goodfellow,Lea and Jones (2008) argue that with increasing access to cutting edge technologies in universities, such as blogging, podcasting and use of video, the growth of online support for academic writing is developing its own momentum. Jones (2009) suggests that the Internet and Web 2.0 technologies are appropriate tools for facilitating writing development in higher education. As part of the online component of the module, digital literacy tutorials were offered to all participants. The series of digital literacy sessions proved especially useful for participants as it opened up for them a dialogue about the role of the scholar in an open, digital world:

Yes research into the mechanics of group work and collaboration helped. I also feel the digital literacy sessions were very beneficial for the class to explain how technologies can be used to encourage collaboration in writing. [Business Lecturer]

The personal reflections which were captured on video, are invaluable as they can now be presented to future cohorts in advance of this module. [Economics Lecturer]

Weller (2011), in coining the phrase digital scholarship, has recognised that whilst it is important to remain critical of much of the hyperbole surrounding new technologies, recognising that previous technological revolutions have failed to transform most academic work, there is a growing recognition across each element of scholarship that digital tools can lead to new and more open ways of working. The use of relevant digital tools will be extended effectively to support academic writing on this module. 


\section{Conclusion}

Research undertaken on the 'Writing and Disseminating Research' module found that four sources of affective writing conditions contribute to academics' perceptions of their ability to overcome writing apprehension: self-efficacy, peer feedback, class community and relevant digital resources. This small scale study using critical incident analysis has suggested that, with enhanced self-efficacy for academic writing, lecturers produce outcomes of better quality, and good writers demonstrate more composing knowledge and metacognitive strategy than they had in previous writing pursuits. Affective knowledge, which requires a writer to be aware of the applicable circumstances and situations of different writing strategies on confidence levels, was considered to be the most influential type of knowledge.

Further research is required into continuing to increase the confidence and affective domain for the academic writers on the module with provision of writing support for skills, literacies and socialisation. The aim is to continue to counteract a writer's isolation by building confidence and engagement.

\section{Acknowledgements}

The author would like to thank all the participants in this study and a former colleague, Ms Martina Crehan, for her contribution to the original module, and the design of the critical incident analysis instrument. 


\section{References}

Al-Mekhlafi, M. (2011) 'The Relationship between Writing Self-efficacy Beliefs and Final Examination Scores in a Writing Course Among a Group of Arab EFL Traineeteachers'. International Journal for Research in Education [online] 29. available from $<$ http://www.fedu.uaeu.ac.ae/journal/docs/pdf/pdf29/2_e.pdf> [13 January 2014]

Angelides, P. (2001) 'The Development of an Efficient Technique for Collecting and Analyzing Qualitative Data: The Analysis of Critical Incidents'. International Journal of Qualitative Studies in Education 14 (3), 429-442

Arkoudis, S. and Tran, L. (2010) 'Writing Blah, Blah, Blah: Lecturers' Approaches and Challenges in Supporting International Students'. International Journal of Teaching and Learning in Higher Education 22 (2), 169-178

Arndt, V. (1992) 'Response to Writing: Using Feedback to Inform the Writing Process'. in Teaching Composition Around the Pacific Rim: Pedagogy and Politics. ed. by Brock, M. and Walters, L. Bristol: Longdunn Press, 90-116

Baikie, K. A., and Wilheim, K. (2005) 'Emotional and Physical Health Benefits of Expressive Writing'. Advances in Psychiatric Treatment 11, 338-346

Beach, R. (1989) 'Showing Students how to Assess: Demonstrating Techniques for Response in the Writing Conference'. in Writing and Response. ed. by Anson, C. M. Urbana, IL: NCTE, 127-148

Benton, S. L., Kraft, R. G., Glover, J. A. and Plake, B. S. (1984) 'Cognitive Capacity Differences among Writers'. Journal of Educational Psychology 76 (5), 820-834

Björk, L., Bräuer, G., Rienecker, L., and Jörgensen, P. S. (eds.) (2003) Teaching Academic Writing in European Higher Education. New York: Kluwer Academic Publishers

Björk, L. and Räisänen, C. (2003) Academic Writing, 3rd Edition: A University Writing Course. Copenhagen: Business School Press

Boulton, H., and Hramiak, A. (2012) 'Writing in the Virtual Environment'. in Writing in the Disciplines: Building Supportive Cultures for Student Writing in UK Higher Education. ed. by Clughen, L. and Hardy, C. Bingley: Emerald Group Publishing Ltd, 99-122

Bransford, J. D., Brown, A. L. and Cocking, R. R. (eds.) (2000) How People Learn: Brain, Mind, Experience, and School. Commission on Behavioral and Social Sciences and Education National Research Council. Washington, DC: National Academy Press

Bruning, R. and Horn, C. (2000) 'Developing Motivation to Write'. Educational Psychologist 35 (1), 25-37

Carter, L. (2008) 'Perceptions of Writing Confidence, Critical Thinking, and Writing Competence among Registered Nurse-Learners Studying Online'. Canadian Journal of University Continuing Education 34 (2), 63-87

Clughen, L., and Hardy, C. (eds.) (2012) Writing in the Disciplines: Building Supportive Cultures for Student Writing in UK Higher Education. Bingley: Emerald Group Publishing Ltd

Coffin, C., Curry, M. J., Goodman, S., Hewings, A., Lillis, T. M. and Swann, J. (2003) Teaching Academic Writing: A Toolkit for Higher Education. London: Routledge 
Cooper, J. and Mueck, R. (1990) 'Student Involvement in Learning: Cooperative Learning and College Instruction'. Journal on Excellence in College Teaching 1, 68-76

Crème, P. and Lea, M. R. (eds.) (2003) Writing at University. Maidenhead: Open University Press

Demirel, E. (2011) 'Take it Step by Step: Following a Process Approach to Academic Writing to Overcome Student Anxiety'. Journal of Academic Writing 1 (1), 212-221

Edvardsson, B. and Roos, I. (2001) 'Critical Incident Techniques: Towards a Framework for Analysing the Criticality of Critical Incidents'. International Journal of Service Industry Management 12 (3), 251-268

Faigley, L., Cherry, R. D., Jolliffe, D. A. and Skinner, A. M. (1985) Assessing Writers' Knowledge and Processes of Composing. Norwood, NJ: Ablex

Flanagan, J. C. (1954) 'The Critical Incident Technique'. Psychological Bulletin 54 (4), 327358

Flower, L. S. and Hayes, J. R. (1981) 'A Cognitive Process Theory of Writing'. College Composition and Communication 32, 365-387

Fraser, K. (1999) 'Australasian Academic Developers: Entry into the Profession and our own Professional Development'. The International Journal for Academic Development 4 (2), 89-101

French, A. (2011) "What am I Expecting and Why?" How can Lecturers in Higher Education Begin to Address Writing Development for their Students?' Journal of Academic Writing 1 (1), 222-227

Gazin, A. (2003) 'Reading and Writing Workshop: Focus on Autobiography'. Education Resources Information Center. [online] available from<http://www.eric.ed.gov/ERICWebPortal/search/detailmini.jsp?_nfpb=true\&_\&ER ICExtSearch_SearchValue_0=EJ602568\&ERICExtSearch_SearchType_0=no\&accno $=$ EJ602568> [11 September 2013]

Goodfellow, R., Lea, M. and Jones, S. (2008) 'Digital Literacies: How Policies and Practices are Blurring Boundaries in Higher Education.' Institute of Educational Technology, The Open University, 1-4. [online] available from <http://oro.open.ac.uk/21165/2/Lea \& Jones.pdf>[11 September 2013]

Graham, S. and Harris, K. (2000) 'The Role of Self-Regulation and Transcription Skills in Writing and Writing Development'. Educational Psychologist 35 (1), 3-12

Green Lister, P. and Crisp, B. R. (2007) 'Critical Incident Analysis: A Practice Learning Tool for Students and Practitioners', Practice 19 (1), 47-60

Hilgers, T.L., Hussey, E.L. and Stitt-Bergh, M. (1999) 'As you're writing, you have these epiphanies: what college students say about writing and learning in their majors'. Written Communication 16 (3), 317-53

Jones, J. (2009) Write-on: Online Support for Academic Writing - A Synthesis of Research and Current UK Projects. UK: The Higher Education Academy

Johnson, D. W. and Johnson, F. P. (2003) Joining Together: Group Theory and Group Skills. Boston: Allyn and Bacon 
Kain, D. (2004) 'Owning Significance: The Critical Incident Technique in Research'. in Foundations for Research: Methods of Inquiry in Education and the Social Sciences. ed. by deMarrais, K. and Lapan, S. D. Mahwah, NJ: Lawrence Erlbaum, 69-85

Kuit, J. A., Reay, G. and Freeman, R. (2001) 'Experiences of Reflective Teaching'. Active Learning in Higher Education 2, 128-142

Lavelle, E. (2006) 'Teachers' Self-Efficacy for Writing'. Electronic Journal of Research in Educational Psychology [online] 4 (1), 73-84. available from <http://investigacionpsicopedagogica.org/revista/new/english/ContadorArticulo.php?88> [13 January 2014]

Mahajan, R. P. (2010) 'Critical Incident Reporting and Learning'. British Journal of Anaesthesia 105 (1), 69-75

McLeod, S. H. (1991) 'The Affective Domain and the Writing Process: Working Definitions'. Journal of Advanced Composition 11 (1), 95-105

Moore, R. A. (2000) 'Preservice Teachers Explore their Conceptions of the Writing Process with Young Pen Pals'. Reading Research and Instruction 40 (1), 17-33

Murray, R. (2013) Writing for Academic Journals. $3^{\text {rd }}$ edn. Maidenhead: McGraw-Hill International

Murray, R. (2006) 'If Not Rhetoric and Composition, Then What? Teaching Teachers to Teach Writing'. in Teaching Academic Writing in UK Higher Education: Theories, Practices and Models. ed. by Ganobcsik-Williams, L. Basingstoke: Palgrave Macmillan,124133

Murray, R., and Moore, S. (2006) The Handbook of Academic Writing. Maidenhead: Open University Press

Nilson, L. (2003) 'Improving Student Peer Feedback.' College Teaching 51 (1), 34-38

O'Connor, P., and Petch, M. (2012) 'Merleau-Ponty, Writing Groups and the Possibility of Space'. in Writing in the Disciplines: Building Supportive Cultures for Student Writing in UK Higher Education. ed. by Clughen, L. and Hardy, C. Bingley, UK: Emerald, 75-97

Pajares, F. (2003) 'Self-Efficacy Beliefs, Motivation, and Achievement in Writing: A Review of the Literature'. Reading and Writing Quarterly 19, 139-158

Scardamalia, M., Bereiter, C. and Goelman, H. (1982) 'The Role of Production Factors in Writing Ability'. in What Writers Know: The Language, Process, and Structure of Written Discourse. ed. by Nystrand, M. New York: Academic Press, 173-210

Speedy, J. (2010) Developing Collaborative Academic Writing Communities. [online] available from<http://www.heacademy.ac.uk/resources/detail/subjects/escalate/5616_Developin g_collaborative_acade> [11 September 2013]

Tripp, D. (1993) Critical Incidents in Teaching: Developing Professional Judgement. London: Routledge

Weller, M. (2011) The Digital Scholar: How Technology Is Transforming Scholarly Practice. London: Bloomsbury 